\title{
SHANGHAIED INTO THE FUTURE: THE ASIANIZATION OF THE FUTURE METROPOLIS IN POST-BLADE RUNNER CINEMA
}

\author{
Marco CERESA \\ Ca' Foscari University of Venice, Dorsoduro 3462, 30123 Venice, Italy \\ E-mail: ceresa@unive.it
}

Received 05 November 2016; accepted 05 May 2017

\begin{abstract}
The clichéd 1930-1950 Western cinematic images of Shanghai as a fascinating den of iniquity, and, in contrast, as a beacon of modernity, were merged in Fritz Lang's Metropolis. As a result, a new standard emerged in science fiction films for the representation of future urban conglomerates: the Asianized metropolis. The standard set by this film, of a dark dystopian city, populated by creatures of all races and genetic codes, will be adopted in most of the representations of future cities in non-Asian cinema. This article traces the representation of Shanghai in Western cinema from its earliest days (1932- Shanghai Express) through Blade Runner (1982) to the present (2013- Her). Shanghai, already in the early 1930s, sported extremely daring examples of modern architecture and, at the same time, in non-Asian cinema, was represented as a city of sin and depravity. This dualistic representation became the standard image of the future Asianized city, where its debauchery was often complemented by modernity; therefore, it is all the more seedy. Moreover, it is Asianized, the "Yellow Peril" incarnated in a new, much more subtle, much more dangerous way. As such, it is deserving of destruction, like Sodom and Gomorrah.
\end{abstract}

Keywords: China, metropolis, science-fiction, cinema, Blade Runner, Metropolis (film), Asianization

\section{Introduction. Shanghaied into the future: what's in a name?}

The clichéd 1930-1950 Western cinematic images of Shanghai as a fascinating den of iniquity, the most corrupt city of an Orient "à la Said" (Said 1978), was made all the more sinister through its dehumanizing exoticism. Moreover, as a beacon of modernity, Shanghai was merged with the daring architectural construction of Fritz Lang's Metropolis. As a result, a new standard emerged in science fiction films for the representation of future urban conglomerates: the Asianized metropolis. The crossover point in this merging process was the film Blade Runner, in which, for the first time, a Western metropolis shows unmistakable signs of sinicization, along with decidedly futurist characteristics. The standard set by this film, of a dark, waterlogged, retrofitted, dystopian city, populated by creatures of all races and genetic codes, will be adopted to various degrees in most of the representations of future cities in non-Asian cinema. The future that awaits the Western global metropolis is definitely Asianized, but also invariably gloomy.
If we look up the word Shanghai in the ODE (Oxford English Dictionary) (OED Online n.d.: s.v. shanghai v.), beside the obvious definition "city on the east coast of China, etc.", we come across a second definition, one more pertinent to our topic:

$$
\text { [...] }
$$

a. Naut. slang (orig. U.S.). To drug or otherwise render insensible, and ship on board a vessel wanting hands.

b. transf. To transfer forcibly or abduct; to constrain or compel. colloq. (orig. U.S. Mil. slang).

$[\ldots]$

According to the OED, the first occurrence of this usage was in 1871, in the N.Y. Tribune, 1 March, in turn quoted in a 1872 book on American-English (Schele de Vere 1872: 347).

Most etymologists claim it originated from the fact that many victims of this practice sailed to the city of Shanghai. The Oxford Dictionary of Chinese Etymology (Onions et al. 1994: s.v. shanghai) states:

"1871, from the practice of kidnapping sailors to serve aboard ships wanting men on 
extended voyages, such as to the Chinese seaport of Shanghai".

One of the most common destinations of the ships with abducted crew members was the port of Shanghai, hence, the term.

According to other sources (Bauer 1988: 283), the verb "to shanghai" entered the maritime lexicon in the 1850s. One source mentions a totally different etymology for this verb, without providing a convincing and consequential explanation, linking it to the practice of surreptitiously dropping a shilling into the hands of an unsuspecting candidate for impressment (Strecker 2014: ch. 1).

The spread of the practice of shanghaiing was made possible since once a sailor signed a contract, known as a "ship article", it was illegal for him to break it before the voyage's end. Moreover, there was a shortage of skilled labor on ships on the West Coast of the United States because of the California Gold Rush. These conditions opened the way for the "crimps", as those who perpetrated the act later known as shanghaiing were originally named: boarding masters who used trickery, intimidation, or violence to put a sailor on a ship (Mcnally 2009). According to the OED, this usage of the word crimp dates from 1718 (OED Online n.d., s.v. crimp, n.2).

Shanghai is, furthermore, the city of sin, and, at the same time, it is also the city of the future. However, the future embodied by the city of Shanghai is most frequently an undesirable one, a future in which women and men often have to resort to despicable means to make a living, not the kind of future someone would embrace out of his free will. Therefore, one often has to be coerced, tricked, or somehow lured into this future. Or shanghaied into it.

\section{Films set in Shanghai and relevant locations}

The present article deals exclusively with the representation of Shanghai as seen through the eyes of non-Chinese (i.e. not from Mainland, Taiwan, HongKong) film makers in fictional films. The only exception being Malu tianshi 馬路天使 (Street Angel), 1937, by Yuan Muzhi 袁牧之, which has been included as the first occurrence in world cinematography of the representation of Shanghai as a built-up urban environment, in which the vertical arrangement mirrored social stratification, as well a first-hand testimony to the Westernized modernity of Shanghai (or of parts of it) in the 30s. Whereas there are many better examples of the latter, such as Tiyu Huanghou 体育皇后 (The Queen of Sports, 1934, directed by Sun Yu 孫瑜), just to mention one, this film remains a rather unique example of the first in Chinese cinematography.

The reason for the exclusion of Chinese films is that we will look here at representations of Shanghai and, in general, of Asianized metropolis of the future in non-Chinese films as Orientalist representations, in the Saidian sense of the terms. Such representations of Shanghai, and of Chinese metropolis, are quite different from their equivalent in Chinese films, which revolve usually around the opposition city vs. country, innocence vs. corruption, naiveté vs. sophistication, or political and military conflicts. In Chinese films, even when the city is perceived in a negative way, its annihilation or chastisement is never advocated. In few cases, the representation of 30s Shanghai as a city rife with crime and corruption coincides in both Chinese and non-Chinese films, (ex. in Yao a yao, yao dao waipo qiao 搖啊搖, 搖到外婆橋 Shanghai Triad, 1995, by Zhang Yimou 张艺谋) but they are taken to different ends and different conclusions. Therefore, for this article, we limit ourselves to non-Chinese films.

\section{Fictional films}

The following is a list of non-Chinese (i.e. not from Mainland, Taiwan, Hong-Kong) fictional films ${ }^{1}$ set wholly or partially in real or soundstage-reconstructed Shanghai. For a more complete, but not totally exhaustive, list also including Chinese titles, see Berra and Ju 2014.

1. Shanghai Express (dir. Josef von Sternberg, USA, 1932), (recreation of Shanghai North Railway Station, now Shanghai Railway Museum, shot in Santa Fe Railroad Depot, San Bernardino, California, USA);

2. Shanghai (dir. James Flood, USA, 1935), (interiors, soundstage recreations);

3. Charlie Chan in Shanghai (dir. James Tinling, USA, 1935), (interiors, soundstage recreations);

4. Le Drame de Shanghaï [The Shanghai Drama] (dir. Georg Wilhelm Pabst, France,1938), (filmed in Cholon, Ho Chi Minh City, and Saigon, Vietnam; Studios Pathé-Cinema, Joinville-le-pont, Val-deMarne, France);

5. Stowaway (dir. William A. Seiter, USA, 1936), (soundstage recreation of Shanghai harbor);

6. Shadows Over Shanghai (dir. Charles Lamont, USA, 1938), (interiors, soundstage recreations);

7. The Shanghai Gesture (dir. Josef von Sternberg, USA, 1941), (Chinese New Year's Eve sequence shot in Chinatown, Los Angeles, California, USA; Hal Roach Studios, Culver City, California, USA);

8. The Lady from Shanghai (dir. Orson Welles, USA, 1947), (filmed at various locations in the USA

1 There are also very many non-fictional films, mostly documentaries.. Among them, especially helpful to understand the role of displaced people in Shanghai, are the documentaries about the Jewish ghetto, such as The Port of Last Resort: Zuflucht in Shanghai, 1998, directed by Joan Grossman and Paul Rosdy (Austria/USA) 
and Mexico. One scene shot in Chinatown, San Francisco);

9. The Shanghai Story (dir. Frank Lloyd, USA, 1954), (filmed at Republic Studios, Hollywood, Los Angeles);

10. Indiana Jones and the Temple of Doom (dir. Steven Spielberg, USA, 1984), (soundstage recreation of 1930s Shanghai Nightclub);

11. Shanghai Surprise (dir. Jim Goddard, USA, 1986), (Hong Kong, Macau, London);

12. Empire of the Sun (dir. Steven Spielberg 1987), (Shanghai: Panyu Road, Changning District, Zhongshan East Road, Huangpu District, the Bund);

13. The Red Violin/ Le Violon rouge (dir. François Girard, Canada / Italy/ USA/ UK/ Austria, 1998), (Shanghai: Hong Zhen Old Street, Hongkou District);

14. Armageddon (dir. Michael Bay, USA, 1998), (establishing shots for the destruction of Shanghai filmed in China);

15. Code 46 (dir. Michael Winterbottom, UK, 2003), (Shanghai: Shanghai Grand Hyatt Hotel, Jin Mao Tower, 88 Century Avenue, Lujiuzui, Pudong New Area);

16. Lara Croft Tomb Raider: The Cradle of Life (dir. Jan de Bont, USA / Germany / Japan / UK, 2003), (soundstage recreation of Shanghai);

17. Gojira: Fainaru Wōzu ゴジラ ファイナルウォーズ [Godzilla: Final Wars] (dir. Ryūhei Kitamura 北村 龍平, Japan / Australia / China, 2004), (Shanghai: Oriental Pearl Tower, 1 Century Avenue, Pudong New Area);

18. The White Countess (dir. James Ivory, UK / USA / Germany / China, 2005), (Recreation of Shanghai Race Course, now Shanghai Art Museum, People's Square, Huangpu District, in addition to stock footage from other sources);

19. Mission Impossible 3 (dir. J. J. Abrams, USA / Germany / China, 2006), (Shanghai: Bank of China Tower, Lujiazui Ring Road, Pudong New Area);

20. The Painted Veil (dir. John Curran, China, USA, Canada, 2006), (recreated in the Shanghai Film Park, a theme-park located in suburban Shanghai);

21. Ultraviolet (dir. Kurt Wimmer, USA, 2006), (Not explicitly set in Shanghai, but partially shot in Shanghai);

22. Fantastic Four: Rise of the Silver Surfer (dir Tim Story, USA / Germany / UK, 2007), (Shanghai: Oriental Pearl Tower);

23. Transformers: Revenge of the Fallen (dir. Michael Bay, USA, 2009), (not shot on location. Shanghai is recreated in studio or via CGI);

24. Shanghai Calling (Daniel Hsia, USA, 2012), (Shanghai: the bar Southern Belle, 433 Chang Le
Road, Xuhui District, which stands for a branch of the American chain Red White \& Brew.);

25. Looper (dir. Rian Johnson, USA / China, 2012), (Shanghai: The Bund, Shanghai Film Park);

26. Skyfall (dir. Sam Mendes, USA/UK, 2012), (Shanghai: Shanghai Pudong International Airport, Shanghai expressway);

27. Her (dir. Spike Jonze, USA, 2013), (Shanghai: Pudong, Zendai Himalayas Center, ZeBar, Lujiazui, Wujiaochang).

\section{Commercial short films}

28. Paris-Shanghai: A Fantasy (2009), by Karl Lagerfeld, created for the French fashion house Chanel's first show in China (soundstage recreation of a Shanghai gambling den and of the Shanghai Express train);

29. First Spring (2009), by Yang Fudong, created for the Italian fashion house Prada's spring/summer collection of 2010 (recreated in the Shanghai Film Park, a theme-park located in suburban Shanghai); 30. Lady Blue Shanghai (2010), by David Lynch, commissioned by the French fashion house Christian Dior for the promotion of the classic Lady Blue handbag (Shanghai: Broadway Mansions Hotel, 20 North Suzhou Road, Hongkou District).

\section{Overview of the Shanghai films}

Of the above, nine titles are dystopian, disaster, superhero, or romantic science-fiction films (n. 14 to 17, 21 to $23,25,27)$, in some of which Shanghai appears in only few scenes, as a backdrop for a battle or duel, often reconstructed in studio or through CGI. Sometimes the name of the city is not even explicitly mentioned, or the city is made to stand in for another city (Los Angeles in Her). Shanghai acts as a backdrop for some breath-taking action in two action spy films (n. 19, 26), the latter of which, a Bond film, features aerial footage of the city in all its "futuristic" glory, shot from a helicopter apparently loaned by the local government.

Five titles are period pieces (n. 10 to 12, 18, 20), mostly set during the civil war period, in the late 30 s, shot on location or with meticulous studio reconstructions. The choice of such historical period is in itself significant: civil war, Japanese occupation, White Russians, displaced persons making a meager living in the decadent city, adventurers and adventuresses, opium, night clubs, taxi-dancers, etc., the stuff Western dreams (or nightmares) of Shanghai are made of. The same atmosphere can be found in films coeval with the period narrated (n. 1 to 7, 9), but, in this case, visual lavishness and extravaganza supersedes accuracy and realism (a characteristic that peaks in The Shanghai Gesture). 
Incidentally, none of these films was shot on location, or in China at all: they are all studio productions, or filmed elsewhere in Asia (Vietnam for Pabst's film), comprehensibly so, given the difficulties of shooting in civil war stricken China.

Within this group, an interesting case is offered by The Shanghai Story (n. 9), an otherwise totally lackluster war-prisoner-cum-thriller low-budget production, which presents a Cold War angle on the Shanghai discourse: the Japanese are the good guys and the "New order" Chinese (the commies?) the villains. The opening voice-over line sums it all up: "Shanghai, the city of shame behind the bamboo curtain".

One title (n. 8) stands out from the rest: Orson Wells's film noir The Lady from Shanghai. This film takes place in New York and San Francisco and the plot is completely unrelated to Shanghai or to China, save that we are told in the beginning that the leading lady comes from Shanghai, where she possibly led a disreputable life.

\section{Before Blade-Runner}

\section{Shanghai as a den of iniquity: where fallen women go}

Shanghai is the city of corruption and decadence, the place of choice for gamblers, traffickers of all sorts, women with a past and men without a future. The place where fallen women thrive and decent women fall, to the point that these women become a metaphor for the city itself. No need actually to show the city in the pictures: the powerfully evocative name of Shanghai and the presence of one of these world-weary ladies is enough to conjure up the most sinful of images.

The only shot, for example, of Shanghai shown in Shanghai Express is a soundstage recreation of Shanghai North Railway Station, as most of the film takes place on the eponymous train, and yet no other film in the entire history of cinema is so evocative of the city and its atmosphere as this one. Cast as a "coaster", "a woman who lives by her wits along the China coast", and adoringly photographed by Josef von Sternberg, Marlene Dietrich delivers a legendary line which sums up the entire Shanghai discourse: "It took more than one man to change my name to Shanghai Lily".

But Shanghai Express is not Von Sternberg's only encounter with the Asian sin city. His Shanghai Gesture contains perhaps the most decadent and sexually depraved depiction of the city ever filmed. Corruption, bribery, blackmail, gambling, alcohol, sexual slavery, suicide, murdering one's offspring - nothing is spared. The action takes place almost exclusively in interiors, in a casino designed like Dante's Inferno. Ruling over the circles of this deliriously baroque Hell is the cynical Mother Gin Sling, whom a heavy yellowface make-up and a marcelled hairdo make her look like some bizarre chinoiserie porcelain idol. The casino is patronized by the usual Shanghai cliché expat crowd: the inevitable White Russian impoverished aristocrat, the Arab gigolo, the Brit who condescendingly speaks pidgin English to a native Chinese, whose English, on the contrary, is impeccable, etc. In walks Victoria, aka Poppy, the spoiled rich girl in search of thrills, played by the exquisite Gene Tierney. In no time the girl, seduced by the Arab gigolo, falls into a spiral of gambling, debts and alcohol, leading to a tragic ending. That's what Shanghai does to decent, albeit spoiled, women. And yet, not a single shot of the city is shown, the very few outdoor scenes being non-descript night takes.

And it is enough to throw in the name of Shanghai to cast a dark aura of intrigue over a story totally unrelated to China. The name of Shanghai and a fallen woman, and there you have a film noir. In the beginning of The Lady from Shanghai, by Orson Wells, the leading lady Elsa, played by an uncharacteristically blond Rita Hayworth, talks about her seedy past, partly speaking in the third person:

Elsa: Her parents were Russian, white Russian. You never heard of the place where she comes from...Gamble? She's done it for a living.

Michael: I'll bet you a dollar I've been to the place where you were born.

Elsa: Chifu.

Michael: It's on the China coast. Chifu. It's the second wickedest city in the world.

Elsa: What's the first?

Michael: Macao. Wouldn't you say so?

Elsa: I would. I worked there... How do you rate Shanghai? I worked there too...You need more than luck in Shanghai.

Just as the name, Shanghai, was sufficient to cast an aura of corruption and vice over the action of a film, without showing much of the actual city itself, the city's name was also tinged with the Western prejudice towards Asia, the "Yellow Peril", but without showing much of the Shanghaiese themselves. The debauchery associated with the city in Western films took place primarily among its foreign population, the gamblers, gigolos, and fallen women. Mother Gin Sling, from the Shanghai Gesture, is a notable exception, but even here, she is played by a Western actress, presenting almost a parody of a Chinese "Dragon Lady", a sinophobic figure that had recently become popular in the West. 


\section{Metropolis}

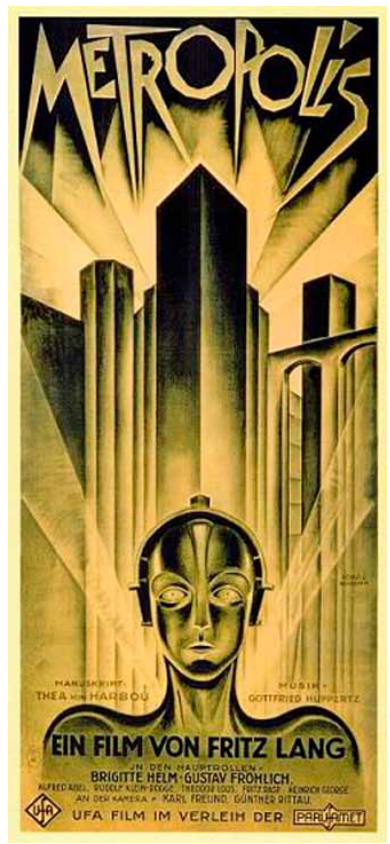

Fig. 1. Metropolis Original 1927 theatrical release poster

Metropolis (Germany, 1927), an epic science-fiction drama by Fritz Lang, is one of the first feature-length movies of the genre (see Fig. 1). Although the first science fiction film is generally considered to be Georges Méliès' Le Voyage dans la Lune (A Trip To The Moon) (1902), which falls rather into the French féerie $^{2}$ tradition, Metropolis is the first to present a generally dystopian vision of an unspecified future city, unidentifiable with any actual place.

A slightly earlier feature length film about space travel, the Soviet Aelita Аэлита, also known as Aelita: Queen of Mars, (1924) by Yakov Protazanov Я́ков Протаза́нов, presents a constructivist Martian city, along with constructivist costumes and sets (see Fig. 2), which may have influenced Fritz Lang's Metropolis. Aelita, which was quite popular in Germany at the time, was especially influential, moreover, on Fritz Lang's subsequent film, Frau im Mond (Woman in the Moon or By Rocket to the Moon, 1929). ${ }^{3}$ However, the

\footnotetext{
2 Féerie was a XIXth century French theatrical genre involving the representation of fairy scenes and characters. It was famous for its fantastic plots, spectacular scenery, and mechanically worked stage effects.

3 Frau im Mond (1929), released in the USA as By Rocket to the Moon and in the UK as Woman in the Moon, was written and directed by Fritz Lang, based on the novel Die Frau im Mond (The Girl in the Moon or The Rocket to the Moon, 1928), by his then wife Thea von Harbou, who had also collaborated with him on Metropolis. It is considered one of the first "serious" (as opposed to Melies' féerie) science fiction films. It presented basics of rocket travel, including the use of a multi-stage rocket and the countdown before the launch, to a mass audience for the first time.
}

future shown in Aelita is an oneiric experience, an escapist fantasy providing relief from the dreariness of daily life in the post-war Soviet Union (which does not prove to be much of an escape, anyway, since the characters in the oneiric future are the same as in present-time daily life, and behave in the same way, for better of worse).

In Metropolis, we see a city of the future (The action takes place in the year 2026 in most versions. However, the year 2000 , or 3000 is cited in others). Society consists of two groups: the management, who live in towering skyscrapers; and the workers, who toil beneath the Earth, little more than slaves to the mercy of Metropolis's clock.

Lang's team of set designers - including Karl Vollbrecht, credited as "film architect", and Erich Kettelhut - were led by Otto Hunte, art director and production designer. Drawing influence from Art Deco, Bauhaus, Cubist and Futurist design, the team worked to conceive a very dark, chiaroscuro illumination of an elongated and almost curiously Gothic city (see Neumann et al. 1999).

Fritz Lang visited New York for the first time in 1924. He reported that "the film was born from my first sight of the skyscrapers in New York in October 1924." and remarked, "I looked into the streets - the glaring lights and the tall buildings - and there I conceived Metropolis". Furthermore, he added "The sight of Neuyork [sic] alone should be enough to turn this beacon of beauty into the center of a film..." (Minden, Bachmann 2000: 4)

Describing his first impressions of the city, Lang said that "the buildings seemed to be a vertical sail, scintillating and very light, a luxurious backdrop, suspended in the dark sky to dazzle, distract and hypnotize" (Lang, Grant 2003: 69).

Curiously, decades later, Blade Runner's director, in order to recreate the future Los Angeles, will recall his experience of another global metropolis, but this time it is a Chinese one: "Hong Kong on a bad day". Almost 60 years separate the two films. If in the 1920s the city of the future, for a German director, was located in America, and it was a scintillating beacon of beauty (even if the beacon would turn out to be very scary one), in the 1980s, for an American film director, the future metropolis was in Asia. Not Shanghai this time, since Shanghai in the 80s was still caught in between old style socialism and market socialism, but its capitalistic equivalent, in terms of colonial and cosmopolitan heritage, on the Pearl River Delta. With its extremely bold verticalism, crammed in a relatively small space, Hong Kong must have appeared more futuristic than any other metropolis of the time, although its modernity was already tainted by chaos, pollution, 
heavy traffic and bad weather. A vertical city where the buildings were interconnected by a system of suspended walkways, its cityscape dominated by a higher element, the Peak: all these features traced this Asian city of the 1980 's back to the cinematic future metropolis of the 1920 's.

The appearance of the city in Metropolis bears a striking resemblance to Italian Futurist architect Antonio Sant' Elia's (1888-1916) design drawings for a futurist "Città Nuova" ("New City"), which was conceived as a symbol of a new age. Many of these drawings were displayed at the only exhibition of the Nuove Tendenze group (of which he was a member) exhibition in Milan, in May/June 1914 (Sant' Elia et al. 1988). However, whereas Sant' Elia's drawings describe a daring and utopian architecture, with strong elements of verticality and features quite unheard of at the time, such as external elevators (see Figs 3 and 10) (which will later appear on the Tyrell Corporation building in Blade Runner. See Fig. 9), Fritz Lang's Metropolis is already retrofitted. It installs modern technology and daring architecture over pre-existing elements, such as "the scientist's

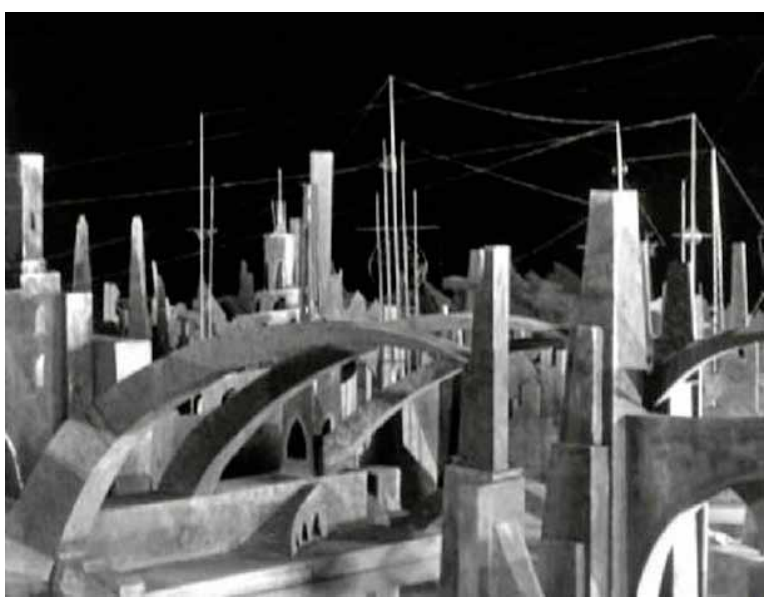

Fig. 2. Aelita (1924): view of a Martian city archaic little house with its high-powered laboratory, the catacombs [and] the Gothic cathedral" (Hoesterey 2001: 49).

Just like the Peak rises over Hong Kong, in Metropolis, as in Blade Runner, the city is dominated by a building that is, in effect, a veritable "Stadtkrone," a "city crown" (see Fig. 8), that crystalline pyramidal form postulated by the German expressionist architect Bruno Taut (1880-1938) (Taut et al. 2015) as the universal paradigm of all religious buildings, which, together with the faith it would inspire, was an essential urban element for the restructuring of society demanding subordination of the individual to the collective good. (Frampton 1980:116). If the function of the Stadtkrone was that of a new religious building capable of unifying the creative energy of the society as Gothic cathedrals

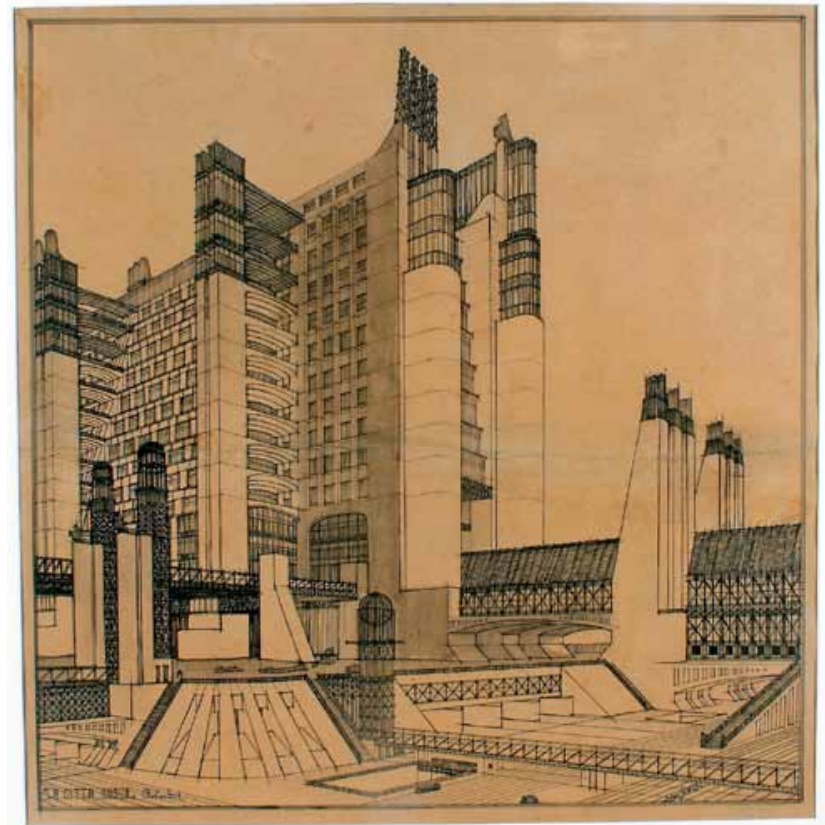

Fig. 3. Antonio Sant'Elia: house with external elevators (1914)

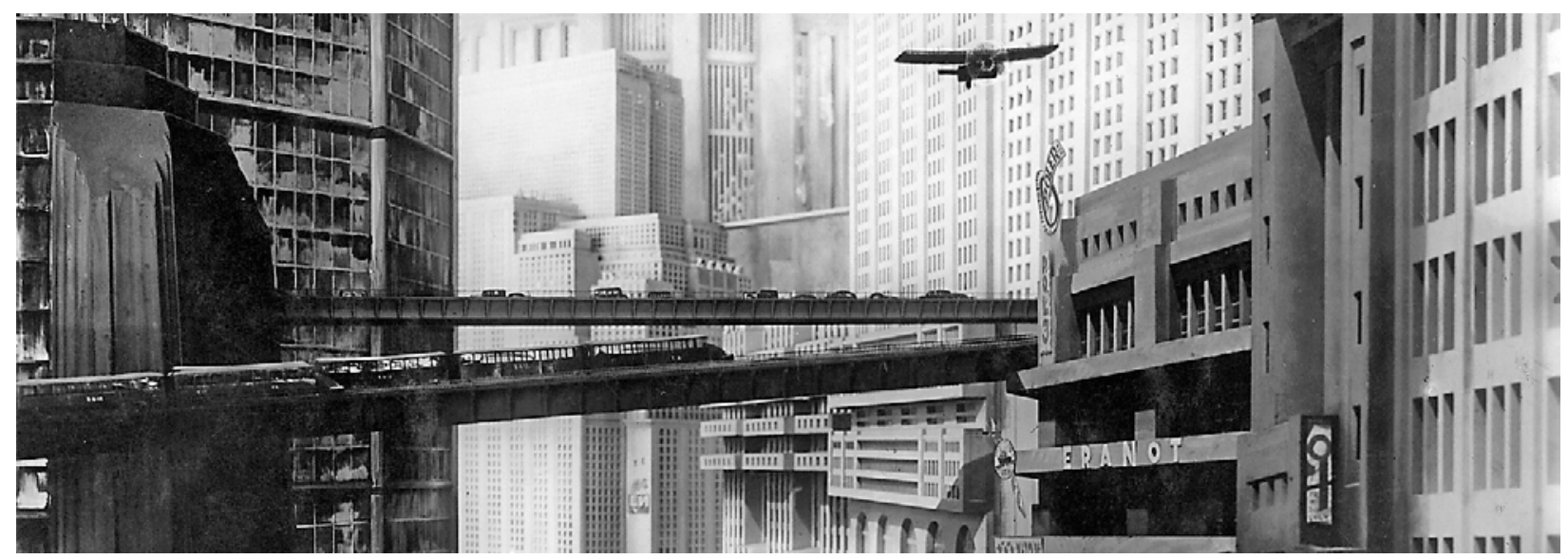

Fig. 4. Fly-over bridges connecting buildings in Metropolis 


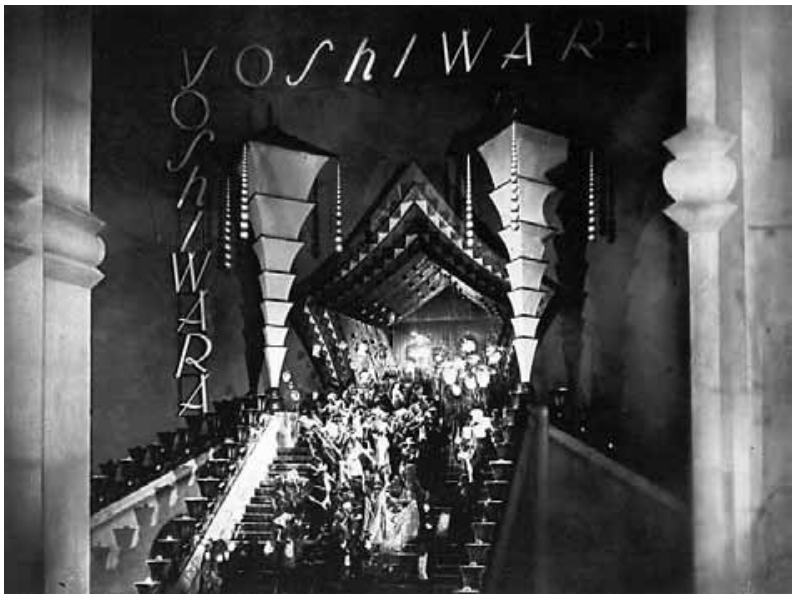

Fig. 5 Metropolis (1927): entrance of the Yoshiwara Club

had been in the Middle Ages, in Blade Runner the religion embodied by the modern Statdkrone, the Tyrell Corporation Building, is genetic manipulation, which allows an Übermenschen master race to create, in a god-like fashion, an Untermenschen slave race of great strength and resistance.

An Asian element, although not a Chinese one, is already present in Metropolis: the Yoshiwara Club (see Fig. 5), named after the famous red-light district Yoshiwara 吉原, founded in Edo, present-day Tōkyō, in the XVII century. The Yoshiwara of Fritz Lang's film conveyed the atmosphere of a 1920s Berlin nightclub, with highly stylized Art Deco "oriental" features. Unfortunately, views of Fritz Lang's Yoshiwara were largely removed from the various prints of the film following the 1927 Berlin premiere, and have resurfaced only recently, after a $16 \mathrm{~mm}$ reduction negative of the original cut of the film was discovered in the archives of the Museo del Cine in Buenos Aires. Some views of the Club survive in still photographs. In one such photograph, an exterior shot of Yoshiwara is seen, with crowds running down the stairs. In another, we see Freder, the leading male character, walking down the stairs early in the morning, after a night of debauchery.

In Metropolis, Asia is already synonymous with decadence and debauchery, via the Japanese Yoshiwara district. In Blade Runner, Chinatown will take over as a den of vice.

\section{Shanghai as a beacon of modernity: Angels over the Metropolis}

Malu tianshi 馬路天使 (Street Angel), 1937, by Yuan Muzhi 袁牧之 is one of the most famous Chinese films of all times. It depicts the daily life of the Shanghaiese Lumpenproletariat in the mid 1930s (Lee 1999). The film stars the iconic singer and actress Zhou Xuan 周 璇 (1918-1957) in the role of a young and innocent

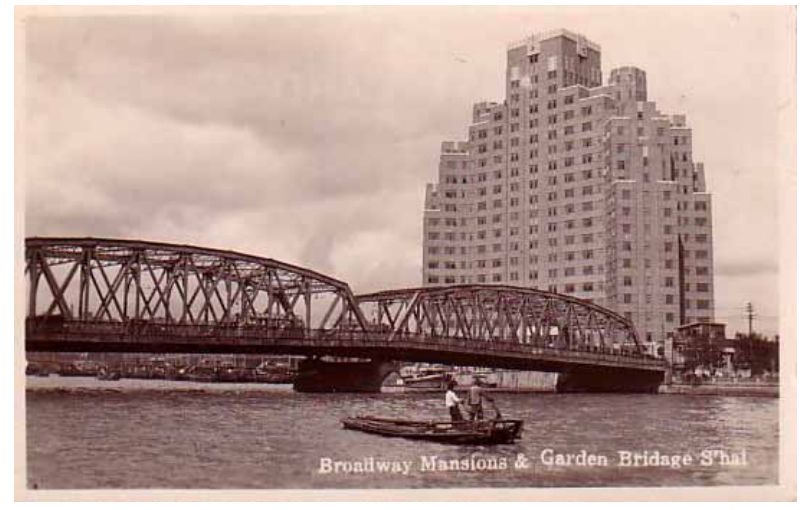

Fig. 6. The Broadway Mansions (1934), in the 1930s

tavern songstress, always surrounded by her trumpeter boyfriend and his very protective beggar friends (the street angels of the title). Its opening title sets the scene: "Autumn 1935. In the world of Shanghai's underclasses". As the opening credits are still rolling, the movie shows us, through a combination of camera movements, the cityscape of Shanghai as a shiny beacon of modernity, all neon lights, western style buildings, theatre marquees, cars, crowds, dancing halls, churches with their chiming bells. Then the camera focuses on the top of a tall, white, deco looking skyscraper, clearly an imaginary maquette, but recalling the Broadway Mansions ${ }^{4}$ (see Fig. 6) or the Park Hotel Shanghai ${ }^{5}$ (see Fig. 7). From there the camera slowly tilts downward to the ground floor and beneath, to the underground, or better, the underbelly of Shanghai, where the poor, the destitute and the outcast live. And most of the story, actually the entire story, with the exception of a brief sequence when two of the protagonists go seeing a lawyer in one of the new shiny high-rise buildings, takes place down there, where it's always dark, where it often rains, where everything looks musty, and rotten, and seedy.

\footnotetext{
4 Broadway Mansions (Bailaohui Dasha 百老匯大廈) is a nineteen-floor Art Deco building, completed in 1934. Upon its completion it became the tallest apartment building in Shanghai and remained so for several decades. The Broadway Mansions was designed by Mr. B. Flazer, and the structural engineer who supervised construction was John William Barrow, both of the architectural firm of Palmer \& Turner, who designed many of Shanghai's other major buildings.

5 The Shanghai Joint Savings Society Building, known today as the Park Hotel or the International Hotel (Guoji fandian 國際飯 店), designed by the Hungarian architect László Hudec, was completed in 1934, a prime example of Art Deco architecture. It was the tallest building in Asia, at 22 floors / $84 \mathrm{~m} \mathrm{(275} \mathrm{ft)} \mathrm{until} \mathrm{1952,}$ and remained so in China until 1966, and in Shanghai until 1983.
} 


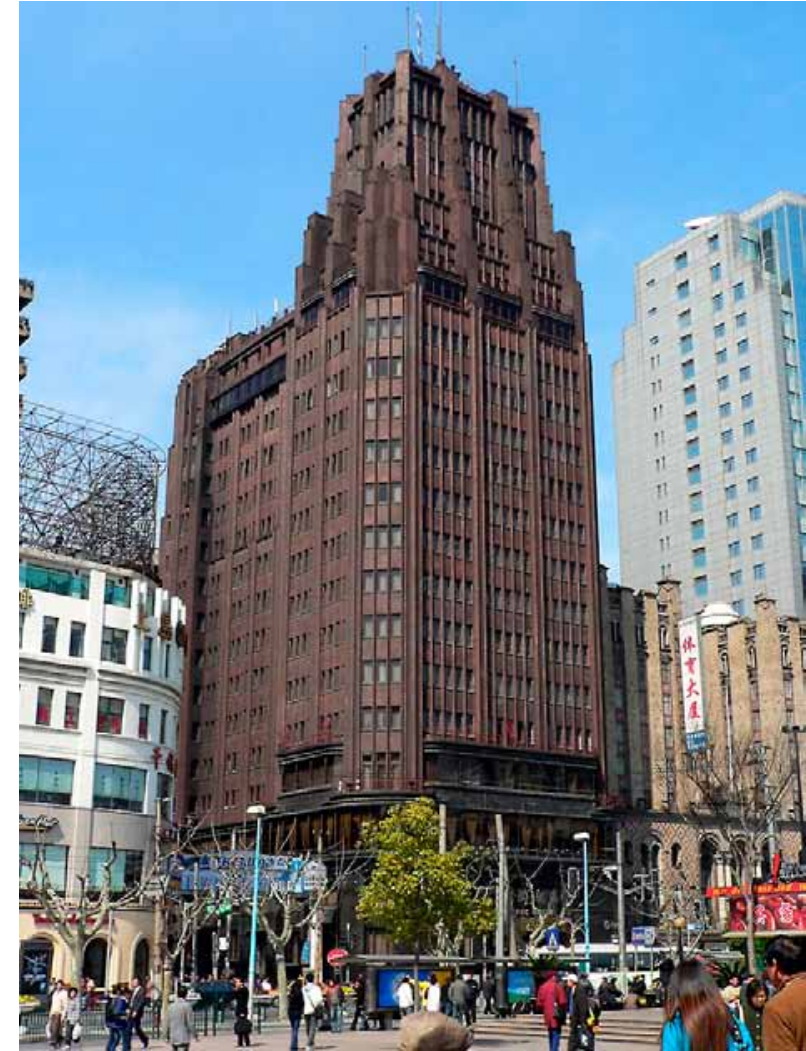

Fig. 7. The Park Hotel Shanghai (1934), recent view

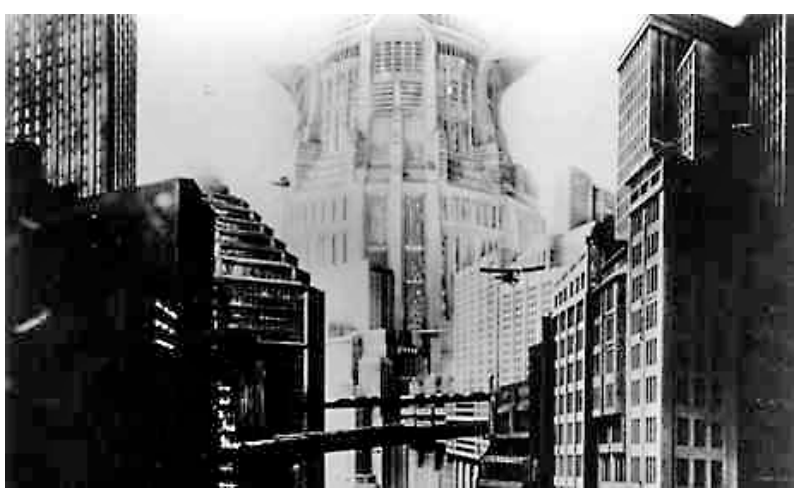

Fig. 8. Metropolis (1927): The Stadtkrone Tower

Actually, the idea of a built-up urban environment, in which the wealthy literally live above the workers, dominated by a huge building - the Stadtkrone Tower in Metropolis and the Tyrell Building in Blade Runnerwas not new to the cinema of the period. Ten years earlier, Fritz Langs's Metropolis (1927) already showed such a dystopian urban setting, a vertical arrangement that corresponded to social stratification.

\section{The Blade-Runner turning point}

Blade Runner (USA, 1982) is where Metropolis' dystopian and architecturally mesmerizing city of the future and Shanghai cinematic "noir" seediness meet to give

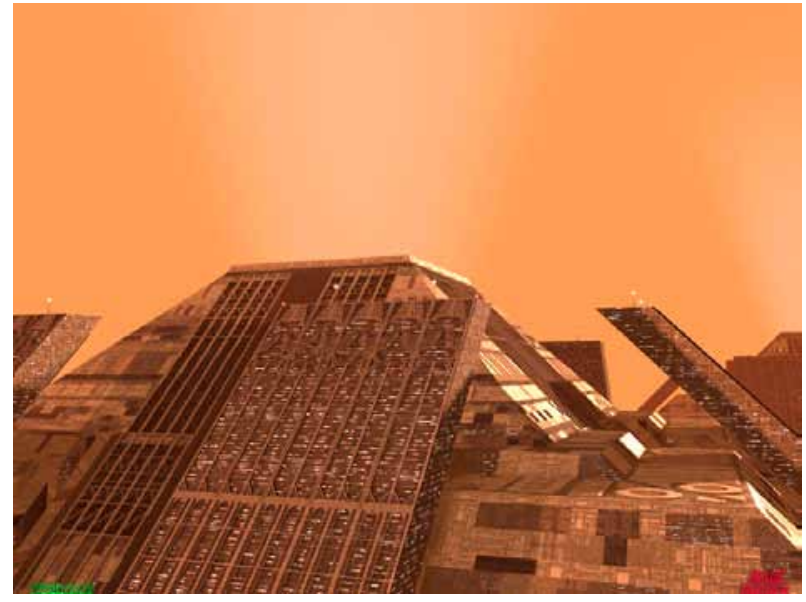

Fig. 9. Screenshot of the Tyrell Corp. from Blade Runner

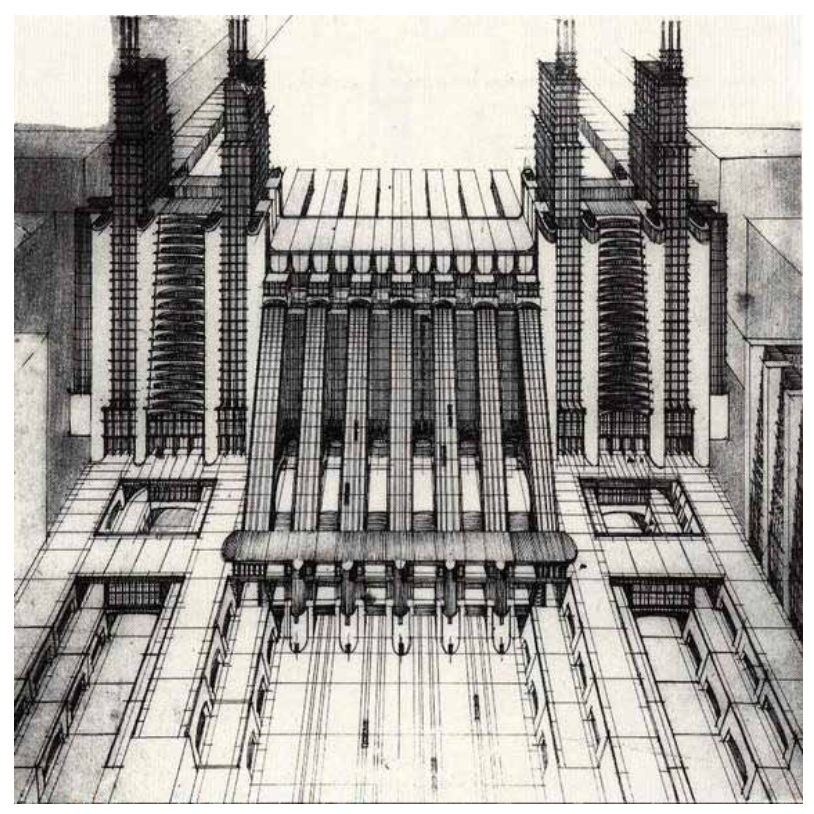

Fig. 10. Antonio Sant'Elia: multi-level railway station (1914)

birth to a new creature: the dystopian Asianized metropolis of the future.

The visuals of this film (which "has already achieved the oxymoronic status of a canonical postmodern cultural artifact" See Doel, Clarke 1997: 140) were based from the very beginning on Asian premises, and so was its gloomy, rain drenched atmosphere. "Hong Kong on a very bad day" (Wheale 1995: 107) is the kind of landscape that inspired Ridley Scott, by his own admission (on the making of Blade Runner, see also Bukatman 2012; Sammon 1996).

Set in 2016 Los Angeles, a city in fact unidentifiable with any actual place (Nowell-Smith 2001: 99), the film shows a built-up urban environment, in which, similarly to Metropolis, the ruling classes live literally on top of the working classes. The latter live their lives at 


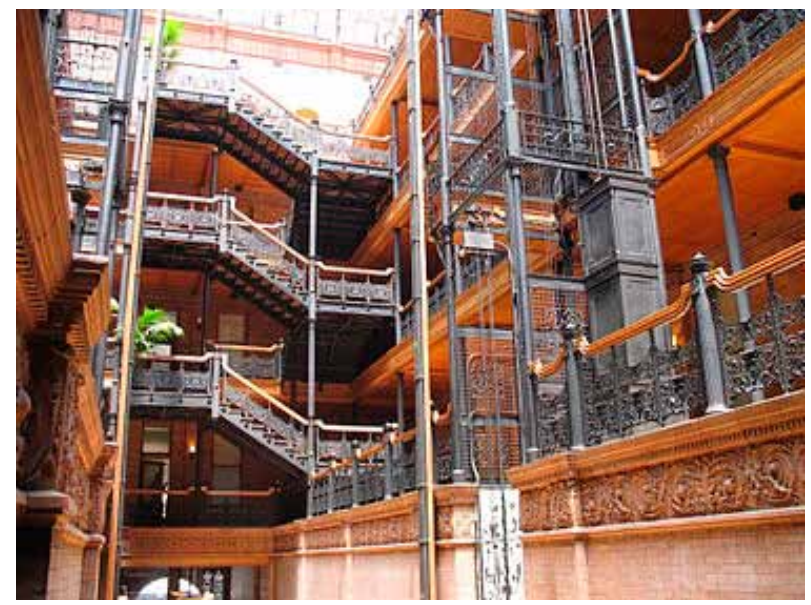

Fig. 11. Interior view of the Bradbury Building

street level, under an incessant, almost tropical rain in a dark and densely populated, decayed urban setting. The Tyrell Corporation Building (see Fig. 9) dominates everything, as the Stadtkrone of this future metropolis, and it is the only spot where the sun ever seems to shine (whether this is real sunlight or a light effect controlled by the almighty Tyrell Corporation, is not clear).

The Blade Runner future is a retrofitted future (Kerman 1991). If signs of such were already present in Fritz Lang's Metropolis, they become much more evident here. Everything is a combination of advanced technology installed over older, outdated structures, or objects. Everything in the lower levels is old, rundown, crumbling to pieces, rotting away, eaten away by the same disease, some sort of leprosy, which is slowly taking the lives of the bioengineered android laborers, the "replicants". For these, their expiration was calculated by their makers, according to the principles of Marcusian planned obsolescence. For the city, there is no expiration date, but no clear future, either. Or redemption. Only a setting of layer upon layer, until the lowest crumbles and dissolves.

Apart from the Tyrell building, two other buildings mark the cityscape, the Bradbury Building, ${ }^{6}$ (see Fig. 11 and 12) and the skyscraper sporting a giant Times Square-like video screen (of the kind that, at the time when the film was shot, existed only in Tōkyō Shibuya district) (see Fig. 13).

6 The Bradbury Building is an architectural landmark located at 304 South Broadway at West 3rd Street in downtown Los Angeles, California. Built in 1893, in what was known at the time as Italian Renaissance Revival style, is the city's oldest landmarked building. The most remarkable part of the building is its interior, which is featured in Blade Runner.

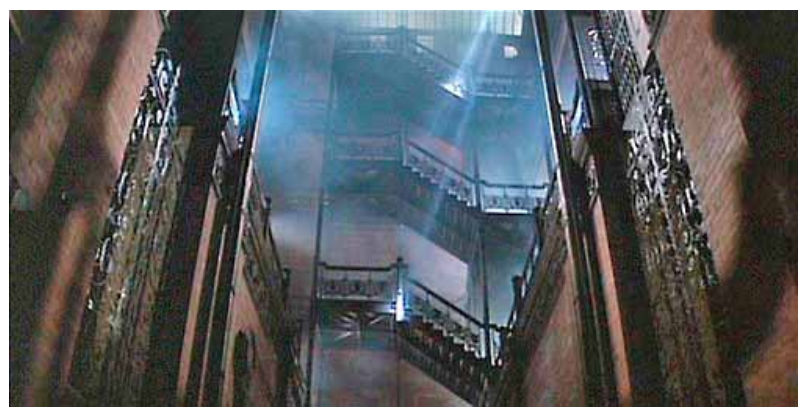

Fig. 12. The Bradbury Building in Blade Runner

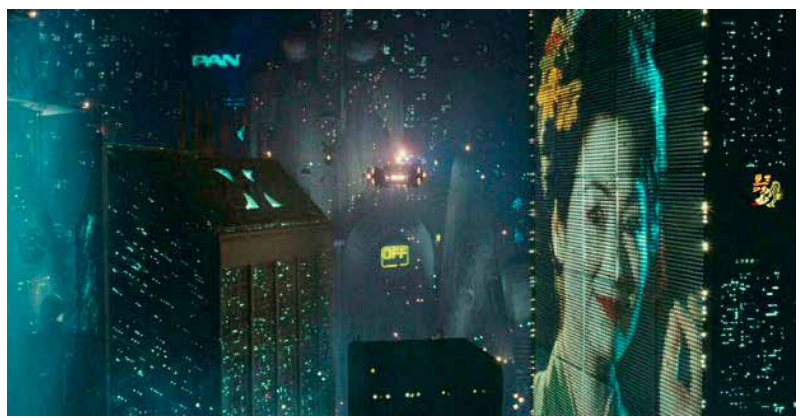

Fig. 13. Blade Runner: giant TV screen on a skyscraper

If the Bradbury Building, with its leprous, exudating walls, isn't but another sign of Blade Runner's retrofitted modernity, the giant TV screen is the first major sign of the Asianization of this future metropolis. The screen features the close-up of a geisha (recalling Metropolis's Yoshiwara Club) swallowing a red pill (a forebearer of The Matrix's red pill?) ${ }^{7}$, accompanied by Japanese traditional music by the ensemble Nipponia. ${ }^{8}$

If all the above mentioned Asian aspects relate to technology and Japan (after all, Tōkyō was the most technologically and architecturally advanced cinematic city at the time the film was shot. See Barber 2002), everything else is Chinatown, or 1930s "noir-esque" Shanghai. The seedy, overcrowded alleys, the nightmarkets, the decadent bar with bizarrely elegant patrons and the sexy "girl with the python" floor-show, everything recalls the fantastic Shanghai of Shanghai Gesture but also of the realistic Shanghai of Street Angels. From Fritz Langs's Yoshiwara Club, to Mother Gin Sling's Casino, to Blade Runner's Chinatown bar, one uninterrupted line of debauchery links the Asian metropolis to the

\footnotetext{
7 The Matrix is a 1999 American-Australian neo-noir science fiction action film written and directed by The Wachowskis.

8 The title of the piece is "Ogi No Mato" or "The Folding Fan as a Target" from the Nonesuch Records release Traditional Vocal and Instrumental Music. The Ensemble Nipponia was formed in 1964 and is dedicated to the performance of traditional and contemporary commissioned work for traditional Japanese instruments.
} 


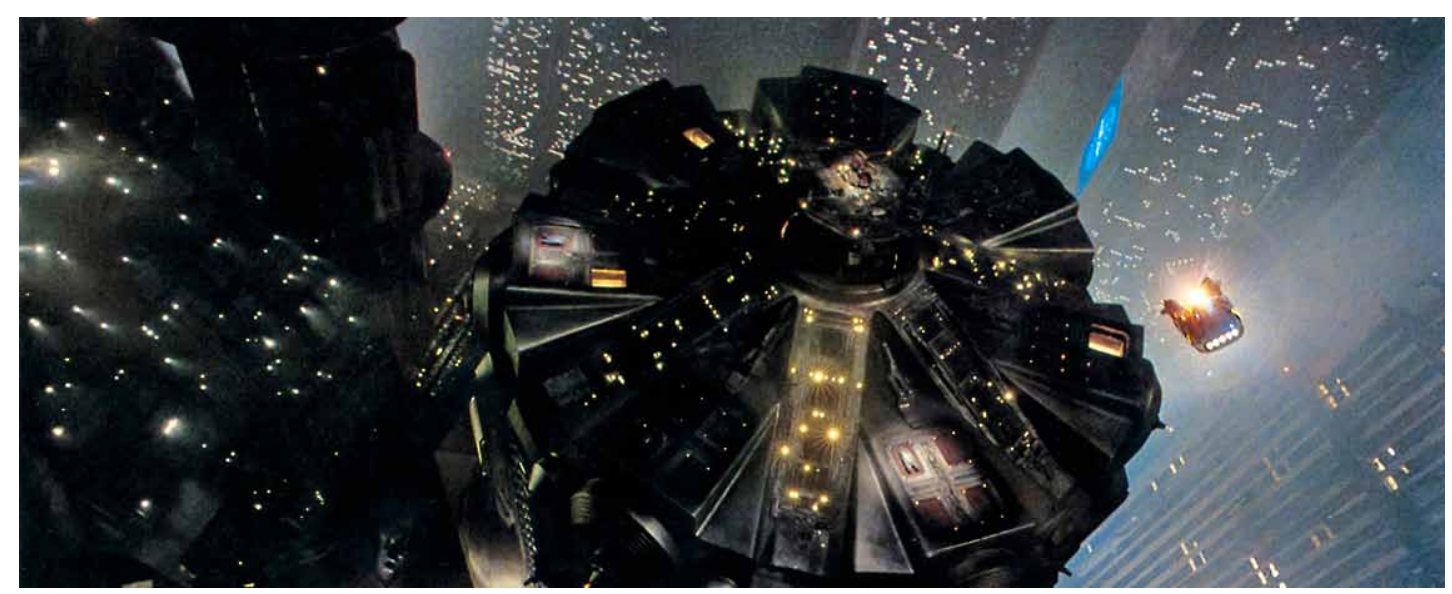

Fig. 14. Spinner (flying vehicle) landing on a building in Blade Runner

Los Angeles of the future. 2016 L.A. is populated by a variety of races and a wide range of languages and pidgins is spoken, but, among the extras and those playing bit parts, it is the Asian or Chinese faces that stick in our mind (the guy in the refrigerated lab where eyes are genetically produced, the noodle-stand owner, the woman who sells artificial animals). The scene where a disgruntled Harrison Ford eats at the Chinese noodle stand has in fact become a classic of future film location: we find a similar scene in the beginning of $L e$ Cinquième Élément (The Fifth Element, by Luc Besson, France, 1997), although this time the noodle stand is floating in mid-air, and the disgruntled guy is Bruce Willis, a freshly out of a job as a flying-cab driver in 2263 New York. ${ }^{9}$ Chinese noodle-stands, flying-cabs and flying-vehicles (called "spinners" in Ridley Scott's film, see Fig. 14), congested urban airways, that's the future metropolis portrayed, albeit briefly, in The Fifth Element. And, once again, it all comes directly from Metropolis and Blade Runner.

\section{After Blade-Runner}

\section{Sci-fi Shanghai: a candidate for destruction}

Shanghai has now surpassed Tōkyō as the city that best represents the futurist potential of the international metropolis. Its skyline, dominated by highrise structures often coming in daring and bizarre shapes, provides the ideal setting for science fiction blockbusters. Shanghai's architecture, particularly its

\footnotetext{
9 In the film, an alarm clock shows the year as being 2263 although the year is given as 2257 on the DVD sleeve notes published by Pathé in 1997, and as 2259 by the director himself in The Story of The Fifth Element.
}

Bund-Pudong area, is more "futuristic" than what can possibly be found anywhere else in the world.

However, in order to make the international audience aware of Shanghai's significance as a global metropolis, its modernity has to be chastised. Shanghai is the designated candidate for destruction, and often is, in fact, destroyed. It doesn't matter whether it's the real Shanghai, or a fictional recreation only bearing the name of the city; it has to be blown-up, maimed, eradicated.

In Armageddon (Michael Bay, 1998) Shanghai is annihilated in a mere two seconds by an asteroid, resulting in NASA's being forced to go public with its plan to save Planet Earth. In the comic book adaptation Fantastic Four: Rise of the Silver Surfer (Tim Story, 2007), Shanghai serves as a backdrop for an epic duel between the superheroes and the supervillain Doctor Victor Von Doom, during which the top of contemporary Shanghai's then most famous landmark, the Oriental Pearl Tower, ${ }^{10}$ (see Fig. 15) is knocked off.

Transformers: Revenge of the Fallen (Michael Bay, 2009) opens with a mission in Shanghai resulting in a series of skirmishes through the city streets, involving explosions and crashes of vehicles and destruction of buildings. What appears to be Shanghai in the film is in fact a mix of two widely separate locations: the old

10 The Oriental Pearl Radio \& TV Tower (Dongfang Mingzhuta, 东方明珠塔) is a TV tower located at the tip of Lujiazui in the Pudong district by the side of Huangpu River, opposite The Bund. The tower was completed in 1994 . At $468 \mathrm{~m}$ (1,535 feet) high, it was the tallest structure in China until 2007, when it was surpassed by another Shanghaiese building, the Shanghai World Financial Center. The tower is brightly lit in different LED sequences at night. This has been in turn surpassed in 2013 by the Shanghai Tower. 


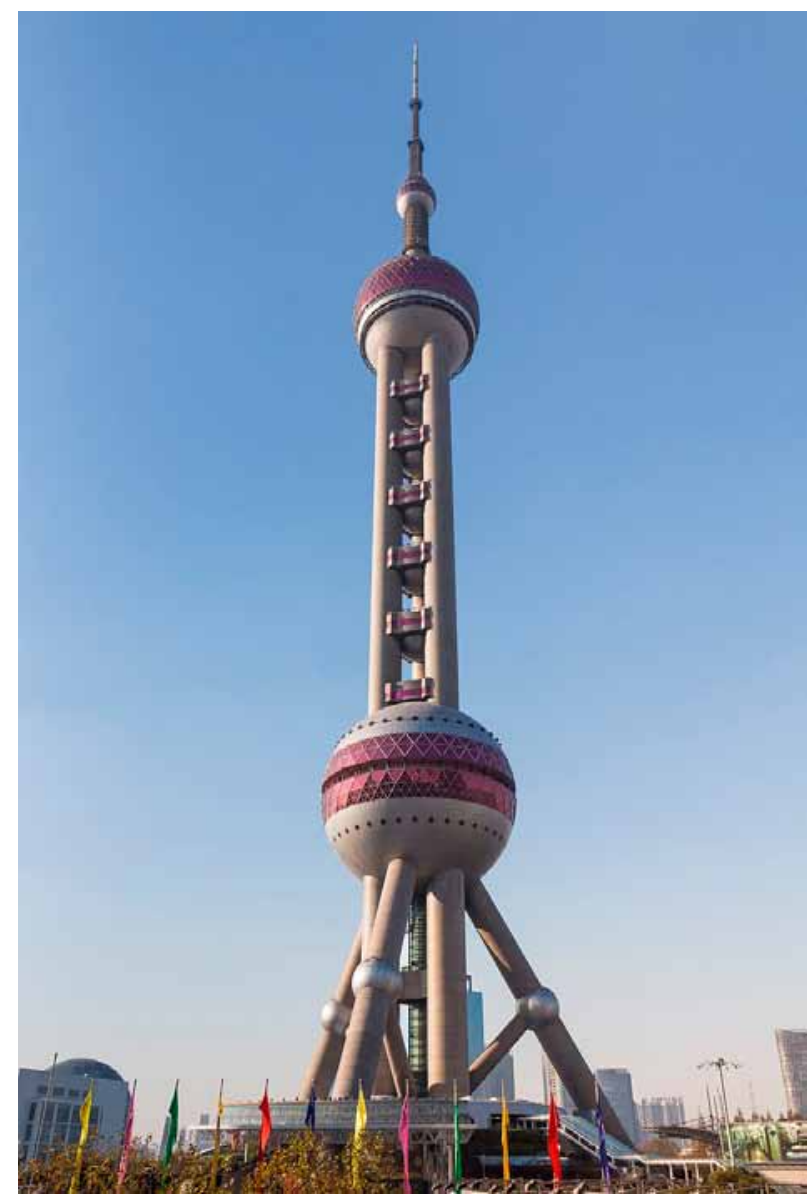

Fig. 15. The Oriental Pearl TV Tower, recent view

Bethlehem Steel ${ }^{11}$ site in Bethlehem, about 60 miles north of Philadelphia, Pennsylvania, and San Pedro Harbor in Long Beach, south of Los Angeles.

Interestingly enough, this vision prevails mostly in international productions of sci-fi films. In contrast, China's film industry has so far been largely reluctant to invest in the genre because of censorship restrictions related to topics such as the depiction of dystopian societies, technological speculation, and anything giving raise to ambiguous political interpretation and identification (Berra, Ju 2014: 89).

Shanghai isn't slated for destruction in all related sci-fi films, but even when it isn't, the city is never showed as a harbinger for a new era of peace, prosperity and

\footnotetext{
${ }^{11}$ Dating from the late XIX century, Bethlehem Steel Corporation was America's second-largest steel producer and largest shipbuilder. The company filed for bankruptcy in 2001 and was subsequently dissolved and its assets sold. The site of the company's original plant in Bethlehem, Pennsylvania, its five blast furnaces still standing, has now been converted into an arts and entertainment district.
}

social equality (for all its socialist grandeur). The only possible exception to this is the film Her (see below).

In the science-fiction romance Code 46 (2003), Shanghai (filmed on location) is one of the restricted areas where the most privileged classes, the urbanites, live. Everybody else is left to struggle at the city's periphery, in shanty-towns bordering the desert. In order to enter the city, one must have the proper identification papers. Once again, the history of Shanghai is linked to displacement of populations and to the possibility of being granted legal access to safe countries, just like what happened to European Jews in the 1930s and 40s. Only, this time, the situation is reversed: Shanghai doesn't grant access to those without papers.

The overly plotted and not entirely consistent science fiction thriller Ultraviolet (2006) combines scenes shot on location in Shanghai and Hong Kong, already architecturally very advanced at the time, to show a 2078 world, highly technological but affected by a mysterious virus. It's a doomed world, in and out of the city, in spite of its super futuristic buildings.

\section{Looper: Shanghai is a gangster future}

Looper is a 2012 American dystopian science fiction action thriller film written and directed by Rian Johnson. The very intricate story takes place in 2044 and in 2074, and the possibility of time travelling plays an important role in the plot, enabling characters from the present and from the future to confront each other within the same scene. This involves also younger and older versions of the same person, conflicting with each other and trying to kill each other. The United States has suffered an economic setback, causing severe social collapse and growth in organized crime and a strange mutation has occurred in $10 \%$ of the population, giving them minor telekinetic powers, of no great consequence for the development of the plot. A lot of people appear to be addicted to a drug, taken in the form of eye drops, which comes in vials significantly bearing a portrait of Mao Zedong. Set in 2044 Kansas, the present-time temporal level does not show any of the "futuristic" elements that usually characterize science-fiction film, especially no display of advanced technology or particularly innovative and daring architecture. Joe's, the main character's, foray into the future, though, is in Shanghai. He is recommended to do so by someone from the future.

Abe: [Joe has been teaching himself French]

Why the $\mathrm{f}^{*} \mathrm{k}$ French?

Joe: I'm going to France. 


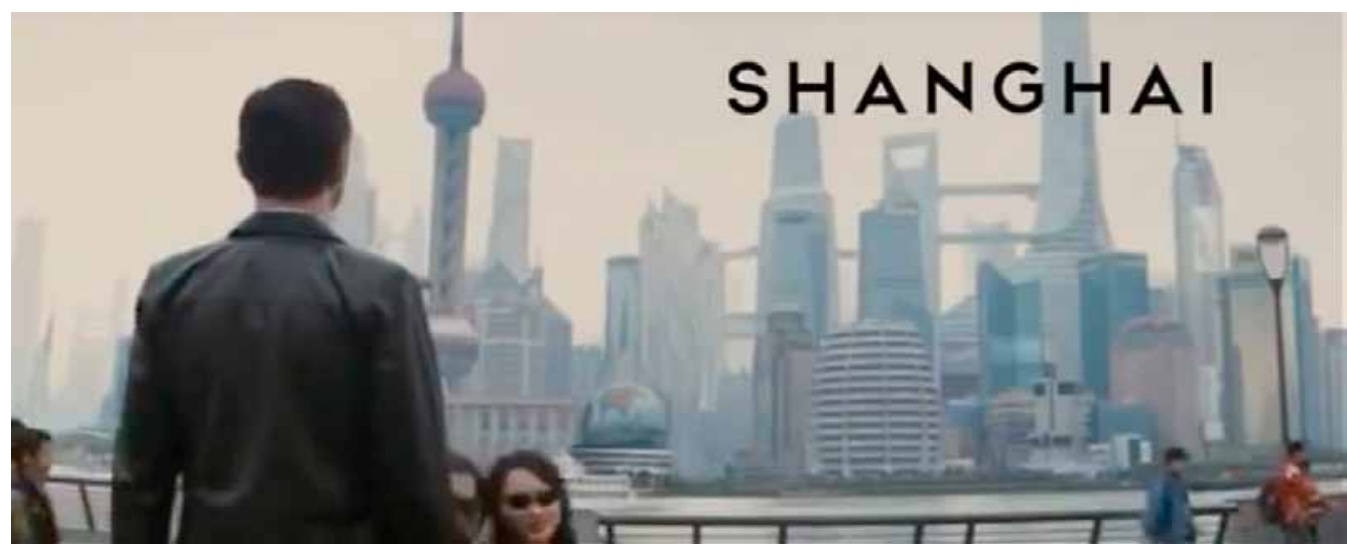

Fig. 16. Looper: view of Pudong from the Bund

Abe: You should go to China.

Joe: I'm going to France.

Abe: I'm from the future. You should go to China.

When it comes to the visual, Looper's Shanghai is just a slightly touched-up version of nowadays Shanghai. If we compare a view of Pudong from the Bund in the film and in reality, we can see that flyover bridges have been added to connect some buildings, but nothing else has been modified (see Figs 16 and 17). On the other hand, suspended walkways, from Sant'Elia's designs to Metropolis and beyond, seem to be a mark of modernity (see Fig. 4), and add on the idea of a multi-layered urban environment, where people live and circulate on different levels. The Mainland China theatrical cut of Looper features extra Shanghai material, requested by Chinese production partner DMG Entertainment, although depictions of drug use were minimized to adhere to local censorship guidelines (Berra, Ju 2014: 114).

Joe's life in Shanghai is all about shoot-ups, murders, sportscars, luxurious penthouses with gorgeous views, drugs, parties, beautiful women. It is an updated version of the old 30's Shanghai. Shanghai is the future, but it is a gangster future.

\section{Her: the future is a sanitized Shanghai}

Her is a 2013 American romantic science fiction comedy-drama film directed by Spike Jonze. The film follows a lonely writer who develops a relationship with an intelligent computer operating system personified through a female voice. The story takes place in Los Angeles, in an unspecified near-future. The filming combined real cityscapes of Shanghai and Los Angeles in order to create a rarified, suspended, technological-

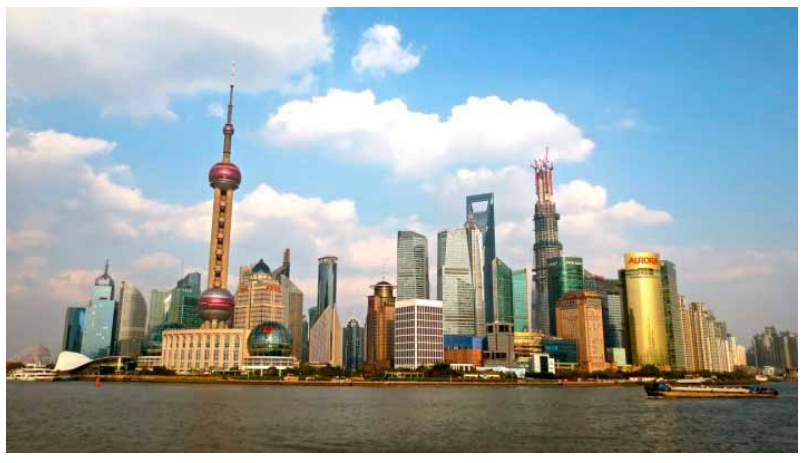

Fig.17. Actual view of Pudong from the Bund

ly super-advanced and super-sanitized urban setting. Shot in the most recently built parts of the Pudong, the newest part of Shanghai, the film does not show the usual post-Blade Runner combination of technology and grime; it is rather the "mise-en-abime" of an urban idealization: the Chinese dream of a sanitizied metropolis within the Californian dream of an airy, uncongested, car-free, effortlessly negotiated urban space. Not a single car appears throughout the entire film. In the real Pudong (as in the film) buildings are often connected by flyover walkways that allow pedestrians to go from building to building without ever having to cross an intersection, and without ever setting foot on the street level. Immediately recognizable are the Lujiazui 陆家嘴 Pedestrian Bridge (see Fig. 18), a circular pedestrian walkway connecting the Pearl Tower and a number of shopping centers, and the Wujiaochang 五角場站 roundabout (see Fig. 19). Once again, it is the Fritz Lang idea of a built-up urban environment, but in this case, it does not correspond to a social stratification. There are no poor people, no outcasts living in the lower levels: it is almost a utopian setting, if it weren't for the de-humanization of 


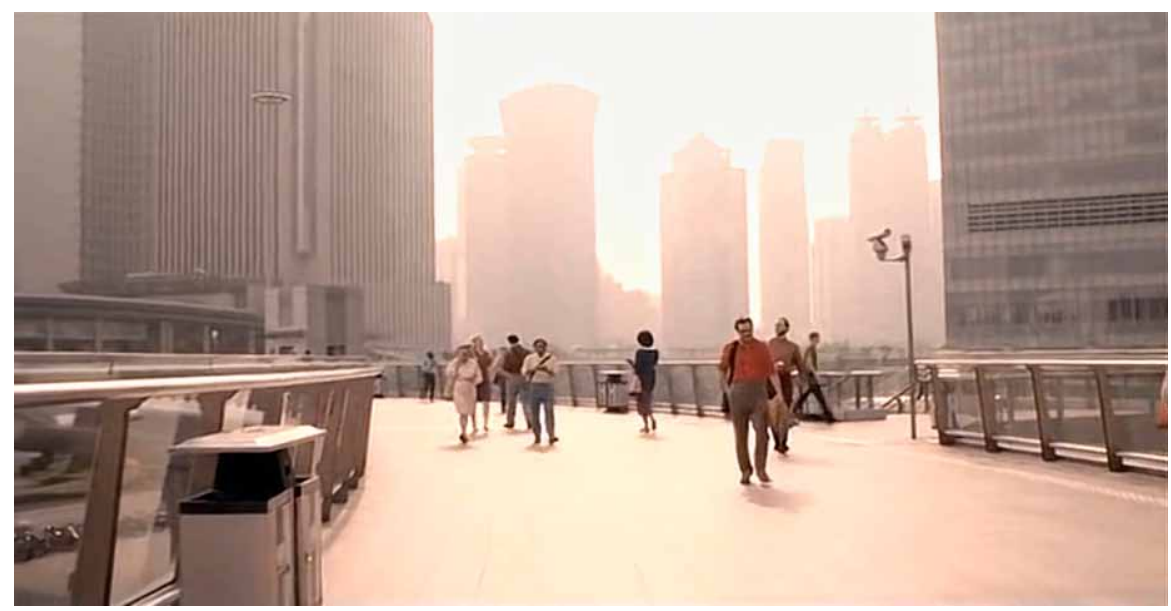

Fig. 18. Her: Shanghai's Lujiazi pedestrian bridge

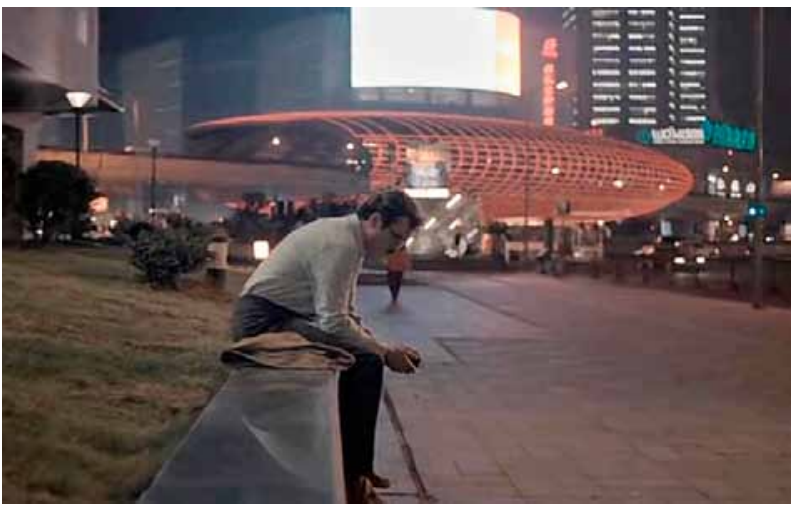

Fig. 19. Her: Wujiaochang roundabout

love-interests. The city is back to its Sant'Eliaesque futuristic utopia, a future not tainted by any physical or ethical leprosy. De-humanization and boredom, yes, but no degeneration. And we can recognize the Asian elements in it simply because, in real life, they are all very well-known, widely published, architectural works, some by non-Chinese architects. Most likely, the average audience, unless it read the final credits to the very end, would not even suspect that the Los Angeles of the film is in fact an architectural pastiche combining Chinese and American cityscapes.

It is hard to tell whether this blending is made possible by the contemporary metropolis in Asia and in the West (Europe, North America) in reality becoming architecturally more and more representative of a generalized international style, or, even, Asian cities, some at least, in fact surpassing Western cities in architectural audacity, thereby becoming a desirable, positive model. Western cities, with a longer tradition of urban and architectural preservation, have proven more resistant to recent most audacious architectural trends; futuristic constructions are placed frequently on the urban peripheries; when they are placed in the city center, such as the Santiago Calatrava's WTC Station in lower Manhattan, they cause scandal and resistance. On the other hand, futuristic urban landscapes such as Shanghai's Pudong can be found in many places in Asia. In this case, the future metropolis would have internalized its Asianness, and become the emblem of the new global city of the future. This is made possible only by its having purged such Asianness of any sordid negativity.

This shift in using the expressive vehicle of Shanghai from an emblem of decadence and corruption, albeit architecturally very advanced, to providing elements of a beacon of shining and sanitized modernity would be a turning point in the history of the representation of China in the West if it could be substantiated with more evidence, beyond that offered by the film Her. It is, however, premature to say. Certainly, the treatment given to China in Western media in terms of corruption and pollution does not seem to point in that direction. Moreover, we should also not discount a certain pressure on China's part on the Western film industry, in terms of investment and possibilities of capturing a large audience, which may lead to a more benign treatment of certain aspects of Chinese society.

It is also significant that despite the dehumanization, and the inclusion of Asian elements in the contemporary urban landscape, the final product is devoid of the overtly sinophobic elements present in earlier cinematographic representations of an Asianized city. The dehumanized city in Her has Asian elements, but they are not readily identifiable as such. Nevertheless, we can justifiably ask why these Asian elements were included in the first place. Couldn't a purely Western 
architectural landscape have been made to appear equally dehumanizing? The architectural landscape in this film, for all its internationalism, projects a threatening coldness that its creators had to go to China to create. The sinophobia is still there, but in a subliminal, subtler form, evident only to the cognoscenti capable of catching the Asian reference.

\section{Asian Metropolis beyond Shanghai: Cloud Atlas' Neo Seoul}

The Asianization of future metropolis seems to be so deeply rooted in contemporary non-Chinese cinematography that, sometimes, when representing a future metropolis is required by the plot, the choice falls directly on an Asian city, fictional or otherwise, thereby skipping the process of Asianizing the Non-Asian. This is the case of Neo Seoul, the fictional future metropolis situated in a dystopian 2144 South Korea, portrayed in the independent science fiction film Cloud Atlas, directed by The Wachowskis and Tom Tykwer (Germany-USA, 2012). The film is an adaptation of the 2004 novel of the same name by the English author, David Mitchell (born 1969). Just as the book does, the film presents multiple plots set across six different eras, and six different locations (or groups of locations). One of them is Neo Seoul, the capital city of Nea So Copros, a short for "New East Asian (Sphere of) CoProsperity", a corporate (non governmental) state set in a unified Korea and surrounding areas.

The population of this corporate society is divided into "pure-bloods" (naturally born individuals) and "fabricants" (genomed clones), created for specific tasks, and to be terminated and recycled after a certain period of time. The reference to Blade Runner's replicants is immediate. Also, the division of society between rulers and slaves, where the latter are tied to their work places and never see the light of the day, reminds us of Metropolis. So does the cityscape of Neo Seoul, a digitally enhanced combination of elements from Fritz Lang's city, and from contemporary Shanghai and Seoul (see Fig. 20). Just like Metropolis, Blade Runner's LA and Street Angel's Shanghai, also Neo Seoul has its underbelly, Huamdonggil, defined in Mitchell's novel as an "Untermensch slum" (Mitchell 2004: 315). In the film, it looks very much like Blade Runner's Chinatown, with its dingy streets full of a motley humanity of outcasts. Cloud Atlas metropolis is not Asianized; it is declaredly Asian, as required by the script and stated in the original novel. What is interesting is the choice by the original writer, and faithfully confirmed by the film directors, to set the "future" part of the plot in an Asian metropolis, whereas all the other parts, present, past and post-apocalyptic, are set in more immediate surroundings (Cambridge, Edinburgh, San Francisco, London), or in more "primitive" natural environments (Pacific island, Hawaii).

The near future metropolis is always an Asian metropolis, declaredly or not. And always on the brink of social collapse.

\section{Conclusions}

Since the film Blade Runner, the image of the future metropolis, with very few exceptions (the film Her), has been that of an increasingly Asianized city, with very advanced architectural and technological features, installed over outdated structures: a retrofit-

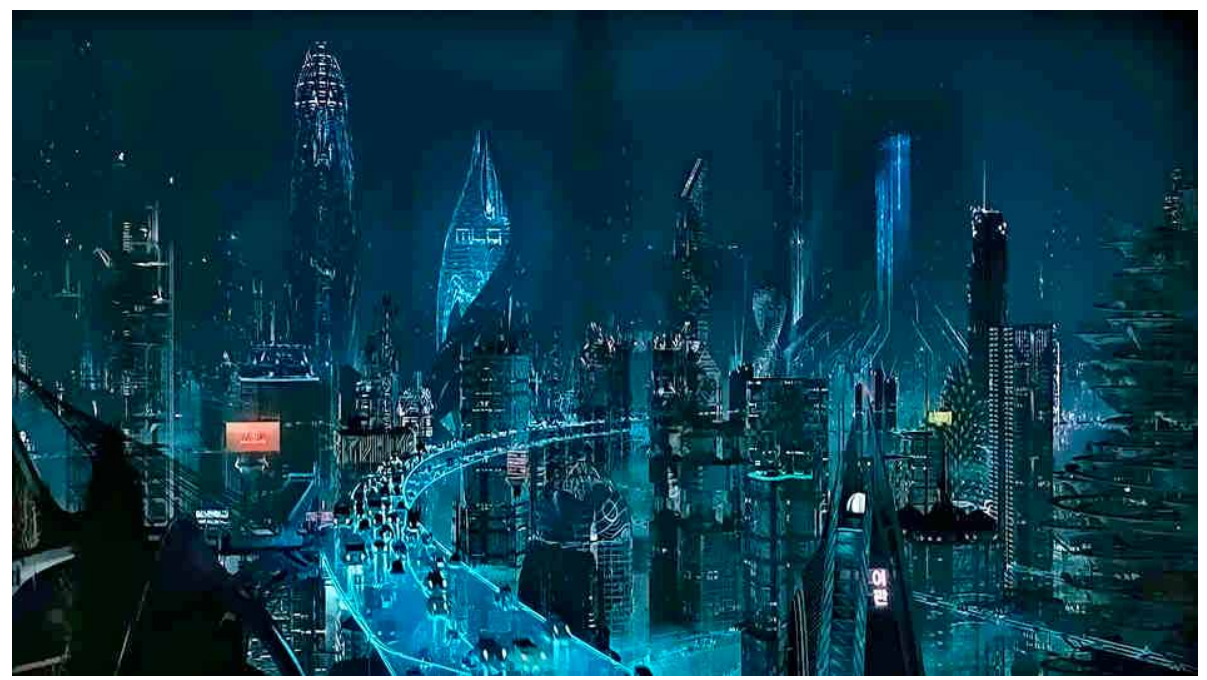

Fig. 20. Cloud Atlas Neo Seoul 
ted and dystopian future. The Asian model for such a metropolis is Shanghai, a city that, already in the early 1930s, sported extremely daring examples of modern architecture. In those days, however, Shanghai's modernity was, in every respect, the mirror image of Western modernity: the architectural firms, and the designers that built Shanghai's greatest architecture were in fact American or European. At the same time, in non-Asian cinema, Shanghai was represented as a city of sin and depravity. From Blade Runner on, this dualistic representation became the standard image of the future Asianized city, where the debauched side was often complemented by, or substituted with modernity, but, therefore, all the more seedy. Perhaps it is no mere coincidence that Shanghai is represented in non-Chinese film alternatively as a futuristic urbanization on the verge of destruction, and a city of sin and depravity.

Ever since Fritz Lang's Metropolis, futuristic cities have been represented in the collective imagination as places of dystopian dehumanization. A major change in the depiction of the Asianized city seems, however, to be taking place, although its nature and direction are still somewhat ambiguous. In the recent film, Her, the futuristic urban society is almost utopian; there is still, nevertheless, an element of dehumanization, preventing intimacy among the city's inhabitants. The new future metropolis is, despite its sanitized version, still dystopian. It is no longer a city of sin and debauchery, but rather of loneliness, isolation, and dehumanization It is the "Yellow Peril" incarnated in a new, much more subtle, much more dangerous way. As such, just like the sordid Asianized city of past decades, it is still deserving of destruction. The modern Sodom and Gomorrah is no longer a place of illicit human contact. It is a place of no human contact at all.

\section{References}

Abrams, J. J. 2006. Mission Impossible 3. USA/Germany/China. Barber, S. 2002. Projected cities. London: Reaktion Books.

Bauer, K. 1988. A maritime history of the United States. Columbia, S.C.: University of South Carolina Press.

Bay, M. 1998. Armageddon. USA.

Bay, M. 2009. Transformers: Revenge of the Fallen. USA.

Berra, J.; Ju, W. 2014. World film locations: Shanghai. Bristol: Intellect Books

Besson, L. 1997. Le Cinquième Élément [The Fifth Element ]. Besson, L. 1997. The story of The fifth element. London: Titan.

Bukatman, S. 2012. Blade runner. London: Palgrave Macmillan on behalf of the British Film Institute.
Curran, J. 2006. The Painted Veil. China/USA/Canada.

de Bont, J. 2003. Lara Croft Tomb Raider: The Cradle of Life. USA/Germany/Japan/UK

Doel M. A.; Clarke, D. 1997. From ramble city to the screening of the eye: Blade Runner, death and symbolic exchange in Clarke, D. 1997. The Cinematic City. London: Routledge, 140-167.

Flood, J. 1935. Shanghai. USA.

Frampton, K. 1980. Modern architecture. London: Thames and Hudson.

Fudong, Y. 2009. First Spring.

Girard, F. 1998. The Red Violin [Le Violon rouge]. Canada/Italy/ USA/UK/Austria.

Goddard, J. 1986. Shanghai Surprise. USA.

Grossman, J.; Rosdy, P. 1998. The Port of Last Resort: Zuflucht in Shanghai. Austria/USA.

Hoesterey, I. 2001. Pastiche: cultural memory in art, film, literature. Bloomington: Indiana University Press.

Hsia, D. 2012. Shanghai Calling. USA.

Ivory, J. 2005. The White Countess. UK/USA/Germany/China.

Johnson, R. 2012. Looper. USA/China.

Jonz, S. 2013. Her. USA.

Kerman, J. 1991. Retrofitting Blade runner. Bowling Green, Ohio: Bowling Green State University Popular Press.

Kitamura, R. [北村龍平] 2004. Gojira: Fainaru Wōzu [ゴジラ ファイナルウォーズ] [Godzilla: Final Wars]. Japan/Australia/ China.

Lagerfeld, K. 2009. Paris-Shanghai: A Fantasy.

Lang, F.; Grant, B. 2003. Interviews. Jackson: University Press of Mississippi.

Lang, F. 1929. Frau im Mond [Woman in the Moon or By Rocket to the Moon].

Lee, L. 1999. Shanghai modern. Cambridge, Mass.: Harvard University Press.

Lloyd, F. 1954. The Shanghai Story. USA.

Lynch, D. 2010. Lady Blue Shanghai.

Mcnally, W. 2009. Evils and abuses in the naval and merchant service. [S.1.]. Applewood Books, U S. (Reprinted from McNally, W. 1839. Evils and abuses in the naval and merchant service, exposed. Boston: Cassady and March)

Méliès, G. 1902. Le Voyage dans la Lune [A Trip To The Moon].

Mendes, S. 2012. Skyfall. USA/UK.

Minden, M.; Bachmann, H. 2000. Fritz Lang's Metropolis. Rochester, N.Y.: Camden House.

Mitchell, D. 2004. Cloud atlas. New York: Random House Trade Paperbacks.

Neumann, D.; Albrecht, D. 1999. Film architecture. Munich: Prestel.

Nowell-Smith, G. 2001. Cities: real and imagined, in M. Shiel, T. Fitzmaurice (Eds). Cinema and the city. Oxford: Blackwell. pp. 99-108.

OED Online. (n.d.). [online], [cited 30 October 2016]. Oxford: Oxford University Press. Available fromInternet:http://dictionary.oed.com/ 
Onions, C.; Burchfield, R.; Friedrichsen, G. 1994. The Oxford Dictionary of English Etymology. Oxford: Clarendon Press.

Pabst, G. W. 1938. Le Drame de Shanghaï [The Shanghai Drama]. France.

Protazanov, Y. [Протаза́нов Я.] 1924. Aelita [Аэли'та] [Aelita: Queen of Mars].

Said, E. W. 1978. Orientalism. New York: Pantheon Books.

Sammon, P. 1996. Future noir. New York: HarperPrism.

Sant'Elia, A.; Caramel, L.; Longatti, A. 1988. Antonio Sant'Elia, the complete works. New York: Rizzoli.

Schele de Vere, M. 1872. Americanisms. New York: C. Scribner \& Co.

Seiter, W. A. 1936. Stowaway. USA.

Spielberg, S. 1984. Indiana Jones and the Temple of Doom. USA.

Spielberg, S. 1987. Empire of the Sun. USA.

Story, T. 2007. Fantastic Four: Rise of the Silver Surfer. USA/ Germany/UK.

Strecker, M. 2014. Shanghaiing sailors. Jefferson, North Carolina: McFarland \& Company, Inc.

Sun, Yu [孫瑜] 1934. Tiyu Huanghou [体育皇后] [The Queen of Sports].

Taut, B.; Baron, E.; Behne, A.; Scheerbart, P.; Mindrup, M.; Altenmüller-Lewis, U. 2015. The city crown by Bruno Taut. Farnham, Surrey, England; Burlington, VT: Ashgate.

Tinling, J. 1935. Charlie Chan in Shanghai. USA. von Sternberg, J. 1932. Shanghai Express. USA.

von Sternberg, J. 1941. The Shanghai Gesture. USA.

Wachowski, L.; Wachowski, L. 1999. The Matrix. USA/Australia.

Welles, O. 1947. The Lady from Shanghai. USA.

Wheale, N. 1995. The postmodern arts. London: Routledge.

Wimmer, K. 2006. Ultraviolet. USA.

Winterbottom, M. 2003. Code 46. UK.

Yuan, Muzhi 袁牧之 1937. Malu tianshi 馬路天使 [Street Angel].

Zhang, Yimou [张艺谋] 1995. Yao a yao, yao dao waipo qiao [搖啊搖, 搖到外婆橋] [Shanghai Triad].

\section{MARCO CERESA}

is the Director of the Department of Asia and North Africa Studies, Ca' Foscari University of Venice, Italy, where he is Professor of Chinese Literature and Cultural Studies. He is also Director of the Confucius Institute at Ca' Foscari, and co-founder and Honorary President of the AICTEA (Italian Association for Tea Studies). Professor Ceresa has published extensively on the history of Chinese tea, Chinese food culture, Chinese cinema, and East Asian cultural studies. 